\title{
Virus-mediated transfer of nitrogen from heterotrophic bacteria to phytoplankton
}

\author{
Emma J. Shelford ${ }^{1}$ and Curtis A. Suttle ${ }^{1,2,3,4}$ \\ ${ }^{1}$ Department of Earth, Ocean and Atmospheric Sciences, University of British Columbia, Vancouver, Canada \\ ${ }^{2}$ Department of Botany, University of British Columbia, Vancouver, Canada \\ ${ }^{3}$ Department of Microbiology and Immunology, University of British Columbia, Vancouver, Canada \\ ${ }^{4}$ Institute of Oceans and Fisheries, University of British Columbia, Vancouver, Canada
}

Correspondence: Curtis A. Suttle (suttle@science.ubc.ca)

Received: 29 June 2017 - Discussion started: 18 July 2017

Revised: 27 November 2017 - Accepted: 8 January 2018 - Published: 9 February 2018

\begin{abstract}
Lytic infection of bacteria by viruses releases nutrients during cell lysis and stimulates the growth of primary producers, but the path by which these nutrients flow from lysates to primary producers has not been traced. This study examines the remineralisation of nitrogen $(\mathrm{N})$ from Vibrio lysates by heterotrophic bacterioplankton and its transfer to primary producers. In laboratory trials, Vibrio sp. strain PWH3a was infected with a lytic virus (PWH3a-P1) and the resulting $36.0 \mu \mathrm{mol} \mathrm{L}^{-1}$ of dissolved organic $\mathrm{N}$ (DON) in the lysate was added to cultures containing cyanobacteria (Synechococcus sp. strain DC2) and a natural bacterial assemblage. Based on the increase in cyanobacteria, $74 \%$ $\left(26.5 \mu \mathrm{mol} \mathrm{L}{ }^{-1} \mathrm{~N}\right)$ of the DON in the lysate was remineralised and taken up. Lysate from Vibrio sp. strain PWH3a labeled with ${ }^{15} \mathrm{NH}_{4}^{+}$was also added to seawater containing natural microbial communities, and in four field experiments, stable isotope analysis indicated that the uptake of ${ }^{15} \mathrm{~N}$ was 0.09 to $0.70 \mu \mathrm{mol} \mathrm{N} \mu \mathrm{g}^{-1}$ of chlorophyll $a$. The results from these experiments demonstrate that DON from lysate can be efficiently remineralised and transferred to phytoplankton, and they provide further evidence that the viral shunt is an important link in nitrogen recycling in aquatic systems.
\end{abstract}

\section{Introduction}

Nutrient recycling is an important link between phytoplankton and heterotrophic bacterioplankton (henceforth referred to as bacteria) in the ocean. Cell death of phytoplankton and bacteria release dissolved organic material (DOM), which is rich in free and combined amino acids (Middelboe and Jørgensen, 2006) that are taken up and metabolised by bacteria (Middelboe et al., 1996, 2003). When the $\mathrm{C}: \mathrm{N}$ of DOM is low relative to bacterial nutritional requirements, bacteria deaminate DOM and release ammonium (Hollibaugh, 1978; Goldman et al., 1987) to acquire carbon for energy and growth (e.g. Brussaard et al., 1996; Fouilland et al., 2014); the release of ammonium can support phytoplankton growth (Haaber and Middelboe, 2009; Weinbauer et al., 2011; Shelford et al., 2012).

Viruses are significant mortality agents of bacteria and phytoplankton in the ocean, and consequently of DOM release (Gobler et al., 1997; Noble and Fuhrman, 1999; Middelboe and Jørgensen, 2006), thereby affecting pathways and rates of nutrient cycling (Fuhrman, 1999; Wilhelm and Suttle, 1999; Suttle, 2005, 2007). Although many nutrients are released during cell lysis, nitrogen typically limits phytoplankton growth in coastal BC waters (e.g. Yin et al., 2017), the location of the current study. High rates of bacterial mortality from viral lysis imply a continuous and substantial flux of DOM from cells into seawater. Weinbauer et al. (2011) provided evidence of the importance of this flux by showing that reducing viral abundance decreased the growth of Synechococcus, the dominant primary producer during their experiments in the Gulf of Mexico and Mediterranean Sea. It was postulated that Synechococcus growth may have been directly stimulated by uptake of dissolved organic nutrients released by lysis, or indirectly through the incorporation of these organics by uninfected bacteria and subsequent remineralisation of inorganic nutrients. Evidence that mineralisa- 
tion of DOM and release of ammonium by uninfected bacteria stimulates phytoplankton growth was shown by Shelford et al. (2012).

The present contribution demonstrates, in the laboratory and field, that uninfected bacteria metabolise dissolved organic $\mathrm{N}(\mathrm{DON})$ released as the result of viral lysis of bacteria and produce ammonium that supports the growth of phytoplankton.

\section{Methods}

\subsection{Laboratory cultures}

A non-axenic semi-continuous culture of Synechococcus sp. strain DC2 (Bigelow, CCMP no. 1334; WH7803), henceforth referred to as Synechococcus, was grown on artificial seawater (Berges et al., 2001), modified by adding $5 \mathrm{mM}$ bicine (Healey and Hendzel, 1979), $124 \mu \mathrm{M} \mathrm{NH}{ }_{4} \mathrm{Cl}$ instead of nitrate, and $13 \mu \mathrm{M} \mathrm{K}_{2} \mathrm{HPO}_{4}$, to ensure a low $\mathrm{N}$ : $\mathrm{P}$ ratio and $\mathrm{N}$ limited growth. Cultures were maintained at $19^{\circ} \mathrm{C}$ and continuous light $\left(42 \mu \mathrm{mol}\right.$ quanta $\mathrm{m}^{-2} \mathrm{~s}^{1}$ photosynthetically active radiation). Experiments were started when cultures entered $\mathrm{N}$ limitation near the end of exponential growth, as determined by epifluorescence microscopy counts.

The Gram-negative marine bacterium Vibrio sp. strain PWH3a (henceforth referred to as Vibrio PWH3a), also known as Vibrio natriegens strain PWH3a (Suttle and Chen, 1992; Weinbauer et al., 1997) and Vibrio alginolyticus strain PWH3a (Poorvin et al., 2011), was grown on artificial seawater with $5 \mathrm{mM}$ bicine, $500 \mu \mathrm{M} \mathrm{NH}{ }_{4} \mathrm{Cl}, 100 \mu \mathrm{M} \mathrm{K}_{2} \mathrm{HPO}_{4}$, and $1 \mathrm{mM}$ glucose as a carbon source for a $\mathrm{C}: \mathrm{N}: \mathrm{P}$ ratio of $60: 5: 1$. The cultures were grown at $25^{\circ} \mathrm{C}$ and continuously mixed at $100 \mathrm{rpm}$. This bacterium was chosen as a model to produce lysates for the current study because it originated from a coastal marine source, and because it has an isolated lytic virus (PWH3a-P1). It is assumed that lysate from Vibrio $\mathrm{PWH} 3 \mathrm{a}$ is a reasonable proxy for DOM produced by viral lysis of marine heterotrophic bacteria, and throughout the manuscript is referred to as bacterial lysate.

Bacteriophage PWH3a-P1 was added in 8-fold excess abundance (multiplicity of infection of $8: 1$ ) to cultures of Vibrio PWH3a at the end of exponential growth, as determined by absorbance at $660 \mathrm{~nm}$ (Ultrospec spectrophotometer, Biochrom, UK). The culture was incubated with the virus until absorbance decreased to $20 \%$ of the initial value ( $\sim 7 \mathrm{~h}$ ). The lysate was filtered through a $0.22 \mu \mathrm{m}$ pore-size Durapore membrane (Millipore, Billerica, MA) and kept at $4{ }^{\circ} \mathrm{C}$ for approximately $20 \mathrm{~h}$. The number of cells lysed prior to filtration was determined by flow cytometry as described below (Sect. 2.4.1). The amount of DON released was determined by the number of cells lysed multiplied by the measured cellular N quota for Vibrio PWH3a, $2.54 \mathrm{fmol} \mathrm{cell}^{-1}$ as described below (Sect. 2.4.4). The result is the amount of total $\mathrm{N}$ released by lysis of Vibrio PWH3a.
Lysates for field experiments were prepared as above, except that Vibrio PWH3a was grown on ${ }^{15} \mathrm{NH}_{4} \mathrm{Cl}$ instead of ${ }^{14} \mathrm{NH}_{4} \mathrm{Cl}\left(90+\right.$ atom $\%{ }^{15} \mathrm{~N}$, Isotec, Miamisburg, OH), and the filtered lysate was kept at $4{ }^{\circ} \mathrm{C}$ for 2 to 5 days until the experiments were initiated. Excess ammonium in the lysate was not removed before adding to the experiments; however, the added ammonium was less than the increase in particulate organic $\mathrm{N}$ (PON) in every field experiment.

\subsection{Growth of Synechococcus on lysate from Vibrio PWH3a}

Water was collected from Queen Charlotte Sound $\left(51^{\circ} 02.37 \mathrm{~N}, 127^{\circ} 52.38 \mathrm{~W}\right)$ on 2 Oct 2011 . Temperature and salinity were $11^{\circ} \mathrm{C}$ and 32 , respectively. Nitrate and phosphate concentrations were 21.3 and $1.9 \mu \mathrm{M}$, respectively. The water was ultrafiltered using a $30 \mathrm{kDa}$ molecular weight cut-off tangential flow cartridge (Prep/Scale, Millipore, Billerica, MA) after pre-filtration through a $0.45 \mu \mathrm{m}$ pore-size polyvinylidene fluoride (PVDF) Durapore membrane (Millipore, Billerica, MA) as outlined in Suttle et al. (1991). The ultrafiltrate was stored in the dark at $4{ }^{\circ} \mathrm{C}$ for a year until used in experiments. Bacteria in the ultrafiltrate grew to a density of $4.18 \times 10^{5}$ cells $\mathrm{mL}^{-1}$, as determined by flow cytometry (described in Sect. 2.4.1), and were used for the remineralisation experiment described below. The bacteria in the ultrafiltrate were derived from the environment and persisted at low nutrient concentrations for an extended period, and hence were more representative of in situ communities than a monoculture. They were an essential component of the laboratory study, where they served as remineralisers.

The experiment combined Synechococcus (Syn), lysate from Vibrio PWH3a, and the bacterial assemblage in ultrafiltrate from Queen Charlotte Sound (Bac) in the following six combinations (Table 1): (1) Syn + Bac + lysate was the experimental treatment with DON from lysate; (2) Syn + Bac was a control for Synechococcus growth in the presence of the bacterial assemblage without a DON source from lysate; (3) Syn + lysate was a control for bacterial remineralisation in the non-axenic Synechococcus culture; (4) Bac + lysate was a control to quantify ammonium remineralisation by the bacterial assemblage with the addition of lysate; (5) Bac only was a control to determine the ammonium concentration of the bacterial assemblage by itself; and (6) Syn only was a control to determine the ammonium concentration and increase in cell number of Synechococcus by itself. All treatments were in triplicate in $1 \mathrm{~L}$ polycarbonate Erlenmeyer flasks (Corning, New York). To each appropriate treatment was added $10 \mathrm{~mL}$ of Synechococcus culture, $100 \mathrm{~mL}$ of bacterial assemblage, and/or $10 \mathrm{~mL}$ of lysate. The experimental treatment volume was $200 \mathrm{~mL}$, and volumes of control treatments were topped up to $200 \mathrm{~mL}$ by adding nitrate- and phosphate-free artificial seawater to control treatments. 
Table 1. Treatments in the laboratory experiment to examine increase in Synechococcus abundance (Syn), in the presence of bacterial lysate from Vibrio PWH3a (lysate), and an environmental bacterial assemblage (Bac).

\begin{tabular}{lrrrrl}
\hline Treatment & Syn $(\mathrm{mL})$ & Bac $(\mathrm{mL})$ & Lysate $(\mathrm{mL})$ & Media $(\mathrm{mL})$ & Aim \\
\hline $\begin{array}{l}\text { Syn + Bac + lysate } \\
\text { Syn + Bac }\end{array}$ & 10 & 100 & 10 & 80 & Experimental treatment \\
Syn + lysate & 10 & 100 & - & 90 & $\begin{array}{l}\text { Control for Syn growth with bacterial } \\
\text { assemblage but not lysate }\end{array}$ \\
Bac + lysate & 10 & - & 10 & $180 \begin{array}{l}\text { Control for remineralisation in non- } \\
\text { axenic Syn culture }\end{array}$ \\
Bac only & - & 100 & 10 & 90 & $\begin{array}{l}\text { Control for remineralisation by } \\
\text { bacterial assemblage }\end{array}$ \\
Syn only & - & 100 & - & 100 & $\begin{array}{l}\text { Control for remineralisation in bacterial } \\
\text { assemblage }\end{array}$ \\
& 10 & - & - & 190 & $\begin{array}{l}\text { Control for Syn growth and } \\
\text { remineralisation }\end{array}$ \\
\hline
\end{tabular}

Table 2. Locations and environmental parameters for field sampling stations: Saanich Inlet (SI), Fraser River Plume (FRP), Semiahoo Bay (SB), and Jericho Pier (JP). Environmental and biological conditions measured include temperature (Temp), salinity (Sal), nitrate (NO$\left.-\mathrm{N}_{3}^{-}\right)$, phosphate $\left(\mathrm{PO}_{4}^{3-}\right)$, ammonium $\left(\mathrm{NH}_{4}^{+}\right)$, and the dominant phytoplankton.

\begin{tabular}{|c|c|c|c|c|c|c|c|c|}
\hline Station & Location & Date & $\begin{array}{r}\text { Temp } \\
\left({ }^{\circ} \mathrm{C}\right)\end{array}$ & Sal & $\begin{array}{l}\mathrm{NO}_{3}^{-} \\
(\mu \mathrm{M})\end{array}$ & $\begin{array}{l}\mathrm{PO}_{4}^{2-} \\
(\mu \mathrm{M})\end{array}$ & $\begin{array}{l}\mathrm{NH}_{4}^{+} \\
(\mu \mathrm{M})\end{array}$ & Dominant plankton \\
\hline SI & $48.592^{\circ} \mathrm{N}, 123.505^{\circ} \mathrm{W}$ & 13 Sep 2012 & 14 & 27.9 & 1.24 & 0.75 & 0.54 & Mixed assemblage \\
\hline FRP & $49.072^{\circ} \mathrm{N}, 123.402^{\circ} \mathrm{W}$ & 13 Sep 2012 & 11 & 28.0 & 10.9 & 1.12 & 0.07 & $\begin{array}{l}\text { Phaeocystis, Skeletonema, } \\
\text { Leptocylindrus }\end{array}$ \\
\hline SB & $49.013^{\circ} \mathrm{N}, 123.037^{\circ} \mathrm{W}$ & 26 Aug 2013 & 20.2 & 29 & 0.00 & 2.40 & 0.08 & $\begin{array}{l}\text { Cyanobacteria } \\
\text { Unknown ciliate }\end{array}$ \\
\hline JP & $49.277^{\circ} \mathrm{N}, 123.202^{\circ} \mathrm{W}$ & 27 Aug 2013 & 19.5 & 21 & 0.00 & 0.20 & 0.11 & Diatoms (mixed assemblage) \\
\hline
\end{tabular}

Treatments were incubated in the laboratory at $19^{\circ} \mathrm{C}$ under continuous light ( $42 \mu \mathrm{mol}$ quanta $\mathrm{m}^{-2} \mathrm{~s}^{-1}$ of photosynthetically active radiation) and sampled daily for cell abundance and ammonium concentration.

\subsection{Uptake of ${ }^{15} \mathrm{~N}$ from lysates in the field}

Water was collected from the surface at Saanich Inlet (SI), the Fraser River Plume (FRP), Semiahoo Bay (SB) and Jericho Pier (JP) in southern coastal British Columbia (Table 2). SI and FRP samples were collected using Go-Flo bottles mounted on a rosette, which held an SBE 25 CTD (Sea-Bird, Bellevue, WA) for measuring temperature and salinity. SB and JP samples were collected by hand using a $20 \mathrm{~L}$ carboy rinsed with $10 \% \mathrm{HCl}$ and ultrapure water, and temperature and salinity were measured with a hand-held thermometer and refractometer. Samples for phytoplankton identification were collected from the whole water and preserved with $\mathrm{Lu}$ gol's acidic iodine solution (Edler and Elbrächter, 2010). The water was filtered through $118 \mu \mathrm{m}$ mesh-size Nitex screening to remove large particulates.

For each experiment, $0.22 \mu \mathrm{m}$ filtered lysate from Vibrio PWH3a was added to Nitex-filtered seawater (SW + lysate) and compared to a control containing $0.22 \mu \mathrm{m}$ filtered seawa- ter (SW). For SB and JP, a third treatment included $0.22 \mu \mathrm{m}$ filtered seawater and $0.9 \mu \mathrm{M}{ }^{15} \mathrm{NH}_{4} \mathrm{Cl}(\mathrm{SW}+\mathrm{N})$ in order to confirm that $\mathrm{N}$ stimulated production and that another factor was not limiting phytoplankton growth, and to mirror the estimated $\mathrm{N}$ contributed by the lysate in the SW + lysate treatment. Treatments were in triplicate. SI and FRP experiments were done in an on-deck flow-through incubator with neutral-density screening to reduce sunlight to approximate in situ irradiance. For SB and JP, experiments were done at $19^{\circ} \mathrm{C}$ and $42 \mu \mathrm{mol}$ quanta $\mathrm{m}^{-2} \mathrm{~s}^{-1}$ continuous irradiance. Samples for cell abundance and ammonium concentration were collected every 6 to $9 \mathrm{~h}$ for 1 to 2 days; samples for chlorophyll $a$ were collected at the initial and final time points, and samples for $\mathrm{PO}^{15} \mathrm{~N}$ were collected at the final time point.

\subsection{Sample analysis}

\subsubsection{Cell and virus counts}

One-milliliter samples were fixed with a final concentration of $0.5 \%$ glutaraldehyde for bacteria and viruses, and $2 \%$ formaldehyde for phytoplankton, and flash-frozen in liquid nitrogen and stored at $-80^{\circ} \mathrm{C}$. Bacteria and viruses were stained with SYBR Green I (Sigma-Aldrich, St. Louis, MO), 
while picophytoplankton were left unstained, immediately before counting by flow cytometry (FACSCalibur, Becton Dickinson, Franklin Lakes, NJ) following the procedures of Brussaard (2004), Gasol and Del Giorgio (2000), and Olson et al. (1993). Larger phytoplankton were preserved with Lugol's solution, and the dominant taxa identified using a settling chamber (Edler and Elbrächter, 2010) and light microscope (Axiovert 10, Zeiss, Canada).

\subsubsection{Nutrient and chlorophyll $a$ collection and analysis}

Samples of $25 \mathrm{~mL}$ were filtered through acid-rinsed syringes fitted with Milli-Q-soaked $0.45 \mu \mathrm{m}$ pore size, $25 \mathrm{~mm}$ diameter, cellulose-nitrate filters (Whatman, UK) in a Swinnex filter holder (Millipore, Billerica, MA). The first $15 \mathrm{~mL}$ was used to rinse the $15 \mathrm{~mL}$ acid-rinsed polypropylene screwcap collection tubes (Sarstedt, Germany), before collecting and freezing the final $10 \mathrm{~mL}$ at $-20^{\circ} \mathrm{C}$ for subsequent nutrient analysis. The filters were folded, placed in aluminum foil packages, and frozen desiccated at $-20^{\circ} \mathrm{C}$ until chlorophyll $a$ was extracted using $90 \%$ acetone and sonication, and analysed fluorometrically (Turner Designs, 10AU fluorometer, Sunnyvale, CA) following Parsons et al. (1984).

Nitrate + nitrite and phosphate concentrations were analysed on a Bran \& Luebbe AutoAnalyzer 3 using airsegmented continuous-flow analysis (Technicon, Oakland, $\mathrm{CA}$ ), while ammonium concentrations were determined fluorometrically (Holmes et al., 1999) using a TD-700 fluorometer (Turner Designs, Sunnyvale, CA).

\subsection{3 $\mathrm{PO}^{15} \mathrm{~N}$ size fractionation, collection, and determination of ${ }^{15} \mathrm{~N}$ enrichment}

For the field experiments, the ${ }^{15} \mathrm{~N}$ incorporated was determined by collecting the particulate material onto combusted $\left(450^{\circ} \mathrm{C}\right.$ for $4 \mathrm{~h}$ ) glass-fibre (GF) filters (nominal pore size of $0.7 \mu \mathrm{m}$, Whatman, UK), which were subsequently dried at $50^{\circ} \mathrm{C}$ for 2 days. Prior to collection onto the GF filters, the SI and FRP samples were poured into a Sterifil (Millipore, Germany) filtration tower fitted with a $1 \mu \mathrm{m}$ pore-size polycarbonate filter (AMD Manufacturing, Canada). While the sample was being gently filtered, the phytoplankton were kept in suspension and rinsed, while the volume was maintained by adding $200 \mathrm{~mL}$ of ultrafiltrate. In this way, cells captured by the $1 \mu \mathrm{m}$ filter were retained for analysis of isotopic enrichment, while smaller cells passed through. Samples for cell counts were taken before and after washing to determine the proportion of cells lost by this process. Samples that were not rinsed with ultrafiltrate were also filtered onto combusted GF filters to estimate the amount of ${ }^{15} \mathrm{~N}$ uptake that was due to bacteria that passed through the $1 \mu \mathrm{m}$ pore size membrane. These GF filters were not rinsed with ultrafiltrate after collecting the sample; hence, if there was noncellular $\mathrm{PO}^{15} \mathrm{~N}$ in the $<1 \mu \mathrm{m}$ size fraction, uptake by the bacterial size fraction would be overestimated. However, there is no reason to expect significant noncellular $\mathrm{PO}^{15} \mathrm{~N}$ in the $<1 \mu \mathrm{m}$ size fraction, and it is uptake by the $>1 \mu \mathrm{m}$ size fraction, which was washed, that is the focus of this study. The $\mathrm{SW}+\mathrm{N}$ treatment (SB and JP) was filtered directly onto GF filters without rinsing. The $\delta^{15} \mathrm{~N}-\mathrm{PON}$ and total PON on the filters was determined at the Stable Isotope Laboratory at Boston University on a GV Instruments IsoPrime isotope-ratio mass spectrometer and a Eurovector elemental analyser, calibrated against atmospheric $\mathrm{N}_{2}$ and IAEA standards $\mathrm{N}-1, \mathrm{~N}-2$, and $\mathrm{N}-3$ (replicate analysis within $\pm 0.2 \%$ ). Due to instrument error, the stable-isotope data for SI and FRP are not replicated; however, duplicates for JP and triplicates for SB were measured.

\subsubsection{Particulate $\mathrm{C}$ and $\mathrm{N}$ analysis}

N cell quotas of Synechococcus and Vibrio PWH3a were determined from cultures grown using the same media and conditions as described in Sect. 2.1. Cultures at the end of exponential phase for Synechococcus as determined by epifluorescence microscopy counts, and mid-exponential phase for Vibrio PWH3a as determined by absorbance, were filtered onto combusted GF filters, dried at $50{ }^{\circ} \mathrm{C}$ for 2 days, and placed in a desiccator until packaged into aluminum foil and analysed on a CHN elemental analyser (Carlo Erba NA$1500)$.

\subsubsection{Calculations and statistical analysis}

Total uptake rates of ${ }^{15} \mathrm{~N}$ in the field experiments were calculated by dividing the total particulate ${ }^{15} \mathrm{~N}$ on the filters by the volume filtered. Normalised uptake rates were calculated by dividing the total uptake rate by the initial chlorophyll $a$ concentration for each incubation. The percent contribution of cells $>1 \mu \mathrm{m}$ to total ${ }^{15} \mathrm{~N}$ uptake was calculated by dividing the total particulate ${ }^{15} \mathrm{~N}$ on the filters of the "washed" samples (adjusted for decrease in phytoplankton abundance) by the ${ }^{15} \mathrm{~N}$ on the unwashed samples.

The differences between initial and final time points for Synechococcus abundances and ammonium concentrations were normally distributed and with equal variances according to Shapiro-Wilk and Levene's tests, respectively; hence, the significance of the results was analysed using one-way analysis of variance (ANOVA). The differences between initial and final time points for bacterial abundances in the laboratory experiment, while normally distributed, had unequal variances, and therefore a Kruskal-Wallis test was performed to test for significant differences.

The differences between initial and final time points for ammonium and chlorophyll $a$ concentrations and bacteria and picophytoplankton abundances were normally distributed (except for the picophytoplankton data for treatment SW in SI, which had only two samples), and with equal variances (except the bacteria data for SI and JP). Significant differences between treatments were determined using twotailed Student's $t$ tests. Data which did not meet the assump- 
tions for the Student's $t$ test were analysed for significant differences using the non-parametric Mann-Whitney $U$ test.

Because the final time point of the bacterial data for the SW + lysate treatment in SI was approximately 6-fold lower than the previous time point, concurrent with a significant increase in viral abundance (data not shown), significance between the two treatments was calculated for the differences between the initial and the fourth time points. The data were normally distributed and had equal variances (Shapiro-Wilk and Levene's tests), and so a Student's $t$ test was run.

\section{Results}

\subsection{Response of N-limited Synechococcus to the addition of lysate}

There was a greater increase in the abundance of N-limited Synechococcus cells exposed to lysate and a remineralising bacterial assemblage than when grown with each component separately; the greatest increase occurred in the treatment Syn + Bac + lysate (Fig. 1a), with final abundances significantly different among all treatments $(p<0.05)$. Ammonium decreased from $\sim 1.0 \mu \mathrm{M}$ to less than $0.2 \mu \mathrm{M}$ except in the Bac + lysate treatment, in which it increased to $8.24 \pm 0.04 \mu \mathrm{M}$ (Fig. 1b), significantly higher than in the other treatments $(p<0.05)$. Bacterial abundance increased in all treatments, but the greatest increases occurred in treatments with lysate addition (Fig. 1c). Bacterial abundance increased in the Syn + lysate treatment, because bacteria were present in the non-axenic Synechococcus and were remineralising (see Fig. 1c Syn + lysate). The bacteria added with the ultrafiltrate (Bac) simply added additional "environmental" bacteria to the treatment and were associated with higher rates of ammonium regeneration.

The proportion of $\mathrm{N}$ released by lysis of Vibrio $\mathrm{PWH} 3 \mathrm{a}$ that was taken up by Synechococcus cells was calculated using the $\mathrm{N}$ cell quotas for Vibrio $\mathrm{PWH} 3 \mathrm{a}$ of $2.54 \mathrm{fmol} \mathrm{cell}^{-1}$, and for Synechococcus of $7.83 \mathrm{fmol} \mathrm{cell}^{-1}$. Based on the decrease in Vibrio PWH3a cells from viral infection, multiplied by the N cell quota of Vibrio PWH3a, approximately $36.0 \mu \mathrm{mol} \mathrm{L}-11 \mathrm{~N}$ was added to each incubation from bacterial lysis (Table 3). The mean percent of $\mathrm{N}$ from lysate that was taken up by Synechococcus cells via remineralisation by bacteria was $74 \%$.

\subsection{Uptake of $\mathrm{N}$ from bacterial lysate by primary producers in field studies}

Lysate from ${ }^{15} \mathrm{~N}$-labeled Vibrio PWH3a cultures was added to seawater from Saanich Inlet (SI), the Fraser River Plume (FRP), Semiahoo Bay (SB), and Jericho Pier (JP; Table 2). Changes were followed in ammonium concentrations and in abundances of bacteria (Fig. 2). Bacterial abundances in SW + lysate treatments were significantly higher than in samples without lysate (SW) by the final time point
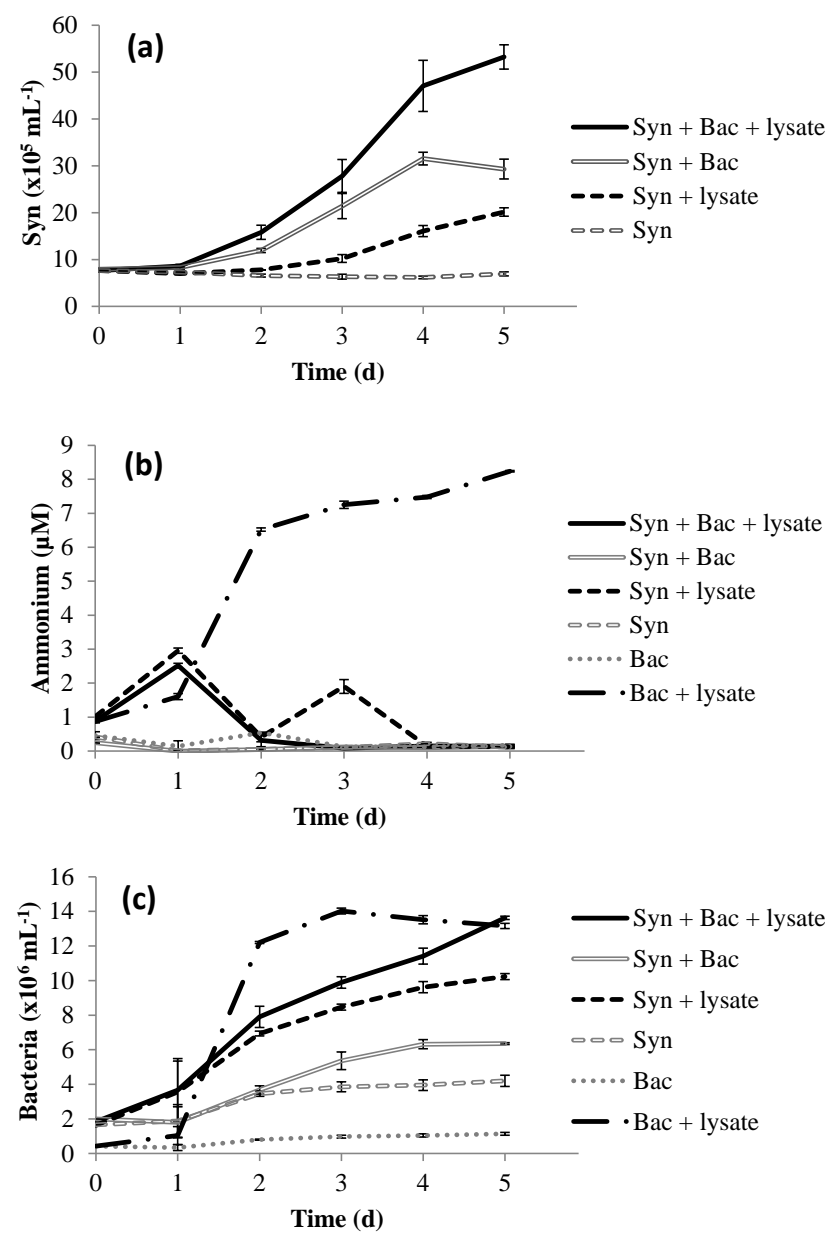

Figure 1. Time series of (a) Synechococcus abundance, (b) ammonium concentration, and (c) bacterial abundance in the laboratory experiment. Error bars are standard error from triplicate incubations.

for FRP, SB, and JP $(p<0.05)$. In the SI sample, bacterial abundances in the treatment with lysate added (SW + lysate) increased almost 10 -fold before decreasing to below initial values by the final time point, concurrent with an increase in viral abundance (see data in the Supplement). There were no significant differences between experimental and control treatments for picophytoplankton abundances, or for chlorophyll $a$ concentrations at the other stations (see data in the Supplement). Ammonium concentrations in SI, SB, and JP decreased to less than $0.2 \mu \mathrm{M}$. In FRP, ammonium concentrations in the SW + lysate treatment decreased to less than $0.04 \mu \mathrm{M}$ by $19.75 \mathrm{~h}$ before both ammonium and bacterial abundance increased concurrently. There was significantly greater drawdown of ammonium in the $\mathrm{SW}+$ lysate treatment at every station except SB $(p<0.05)$. The increase in bacteria and greater ammonium uptake at most stations indicate that bacterial growth and overall uptake of ammonium were enhanced in these samples by the addition of bacterial lysate. 
Table 3. Vibrio sp. strain PWH3a dynamics during the creation of lysates by viral infection (Laboratory: experiments with cultured Synechococcus; SI: Saanich Inlet; FRP: Fraser River Plume; SB: Semiahoo Bay; JP: Jericho Pier). N was added at lower concentrations for stations SB and JP to approximate in situ concentrations.

\begin{tabular}{|c|c|c|c|}
\hline & Laboratory & SI and FRP & SB and JP \\
\hline Vibrio $\mathrm{PWH} 3 \mathrm{a}$ abundance pre-virus $\left(\right.$ cell $\left.\mathrm{L}^{-1}\right)$ & $3.96 \times 10^{11}$ & $7.87 \times 10^{11}$ & $7.89 \times 10^{10}$ \\
\hline Vibrio $\mathrm{PWH} 3 \mathrm{a}$ abundance post-virus incubation $\left(\right.$ cell $\left.\mathrm{L}^{-1}\right)$ & $1.12 \times 10^{11}$ & $9.43 \times 10^{10}$ & $6.38 \times 10^{10}$ \\
\hline Total $\mathrm{N}$ release $\left(\mu \mathrm{mol} \mathrm{L}{ }^{-1}\right)$ & 721 & 1760 & 38.4 \\
\hline $\mathrm{N}$ addition to experimental incubations $\left(\mu \mathrm{mol} \mathrm{L}{ }^{-1}\right)$ & 36.0 & 67.7 & 0.44 \\
\hline $\mathrm{N}$ addition to experimental incubations $(\mu \mathrm{mol})$ & 7.21 & 33.8 & 0.31 \\
\hline
\end{tabular}
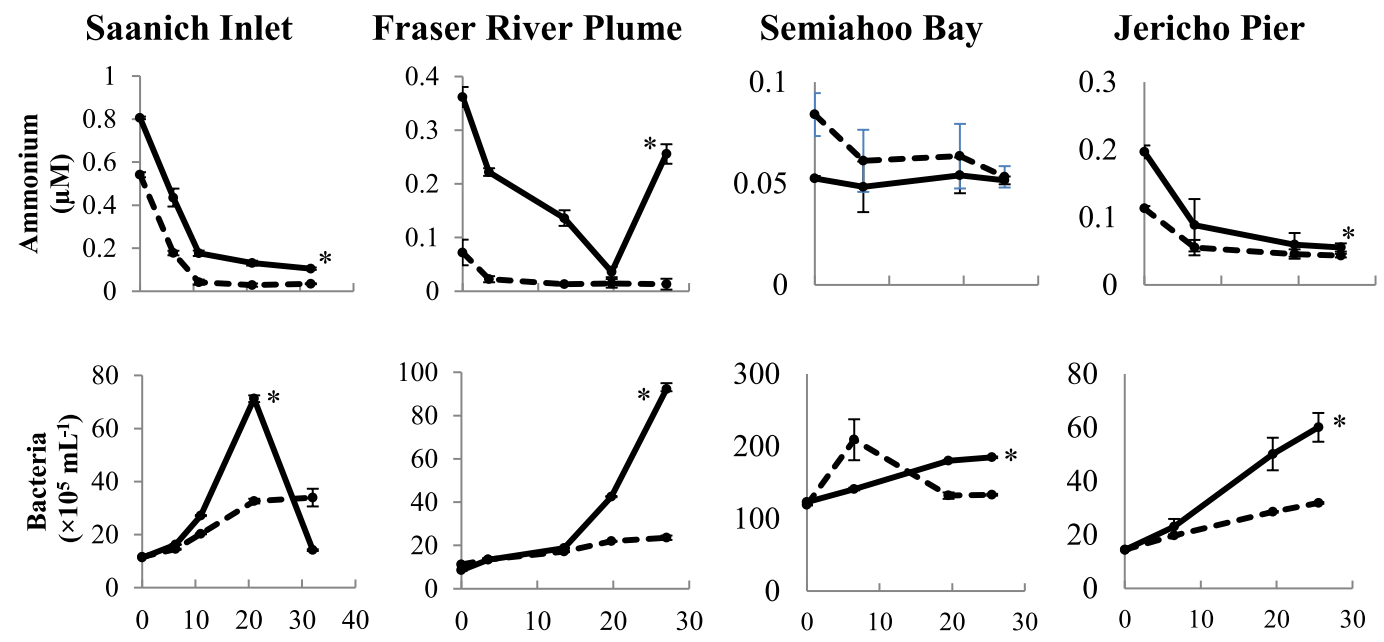

Time (h)

Figure 2. Time course of ammonium concentrations and bacterial abundances in the field experiments. Solid and dashed lines indicate treatments with lysate addition (SW + lysate) or without (SW), respectively. Error bars are standard errors of triplicate incubations. Asterisks indicate significant differences between treatments. Note that the scales are different among plots.

There was uptake of lysate-derived $\mathrm{N}$ by cells $>1 \mu \mathrm{m}$, which would be comprised primarily of phytoplankton. The addition of lysate to the $\mathrm{SW}+$ lysate treatment for each station contributed approximately $67.7 \mu \mathrm{mol} \mathrm{L}^{-1} \mathrm{~N}$ for SI and FRP, and $0.44 \mu \mathrm{mol} \mathrm{L}^{-1} \mathrm{~N}$ for SB and JP (Table 3). To more closely reflect ambient concentrations, the amount of lysate $\mathrm{N}$ added to SB and JP was greatly reduced compared to the two previous experiments. Stable isotope data from PON collected on $0.7 \mu \mathrm{m}$ pore-size glass-fibre filters indicated uptake of lysate by the particulate fraction (Table 4; Fig. 3). From the ${ }^{15} \mathrm{~N}$ data, the calculated contribution to the total uptake by cells in the $>1 \mu \mathrm{m}$ size fraction was $46.3 \%$ (SI), $47.6 \%$ (FRP), and $100 \%$ (SB and JP). The large (>50\%) contribution of the bacterial size fraction to ${ }^{15} \mathrm{~N}$ uptake in SI and FRP (Fig. 3) corresponded to an increase in bacterial abundances (Fig. 2).

There was uptake of ${ }^{15} \mathrm{NH}_{4}$ in the $\mathrm{SW}+\mathrm{N}$ treatment, with $0.61 \pm 0.20 \mu \mathrm{mol} \mathrm{L}^{-1} \mathrm{~N}(\mathrm{SB})$ and $0.44 \pm 0.26 \mu \mathrm{mol} \mathrm{L}^{-1} \mathrm{~N}$ (JP) taken up into the particulate fraction (corrected for 90 atom $\%{ }^{15} \mathrm{~N}$, data not shown); therefore, ammonium pro- duced by remineralisation of lysate in the SW + lysate treatment could be used by the microbes at these two stations.

\section{Discussion}

Experiments in the laboratory and with natural systems demonstrate that $\mathrm{N}$ in viral lysates can be remineralised by bacterial communities to fuel primary production. Studies have shown that lysis by viruses produces bioavailable DOM (e.g. Middelboe et al., 2003; Poorvin et al., 2004), and that phytoplankton lysate can be remineralised (Gobler et al., 1997). Other studies have provided evidence that ammonium from remineralisation may stimulate primary production (Haaber and Middelboe, 2009; Weinbauer et al., 2011; Shelford et al., 2012); yet, data are lacking on the mechanism involved in the transfer of $\mathrm{N}$ to primary producers from bacterial lysates produced by viral infection. This study shows that phytoplankton in culture and in environmental samples take up $\mathrm{N}$ from bacterial lysates, and that ammonium produced through bacterial remineralisation of DON enables that uptake. 
Table 4. Uptake by the particulate fraction of ${ }^{15} \mathrm{~N}$ from bacterial lysate from four field stations, and the same uptake normalised by initial chlorophyll $a$ concentrations. Error measurements are standard error of triplicate incubations for SB, and range of duplicate incubations for JP. SI and FRP are singleton measurements.

\begin{tabular}{lrrr}
\hline & $\begin{array}{r}\text { Total uptake } \\
\text { of }{ }^{15} \mathrm{~N} \\
(\mu \mathrm{mol})\end{array}$ & $\begin{array}{r}\text { Total uptake } \\
\text { of }^{15} \mathrm{~N} \\
\left(\mu \mathrm{mol} \mathrm{L}^{-1}\right)\end{array}$ & $\begin{array}{r}\text { Uptake of }{ }^{15} \mathrm{~N} \\
\text { normalised by } \\
\text { chlorophyll } a \\
\left(\mu \mathrm{mol} \mu \mathrm{g}^{-1}\right)\end{array}$ \\
\hline Saanich Inlet (SI) & 0.83 & 1.67 & 0.27 \\
Fraser River Plume (FRP) & 0.88 & 1.76 & 0.70 \\
Semiahoo Bay (SB) & $0.42 \pm 0.01$ & $0.60 \pm 0.02$ & $0.70 \pm 0.16$ \\
Jericho Pier (JP) & $0.35 \pm 0.04$ & $0.50 \pm 0.1$ & $0.09 \pm 0.00$ \\
\hline
\end{tabular}

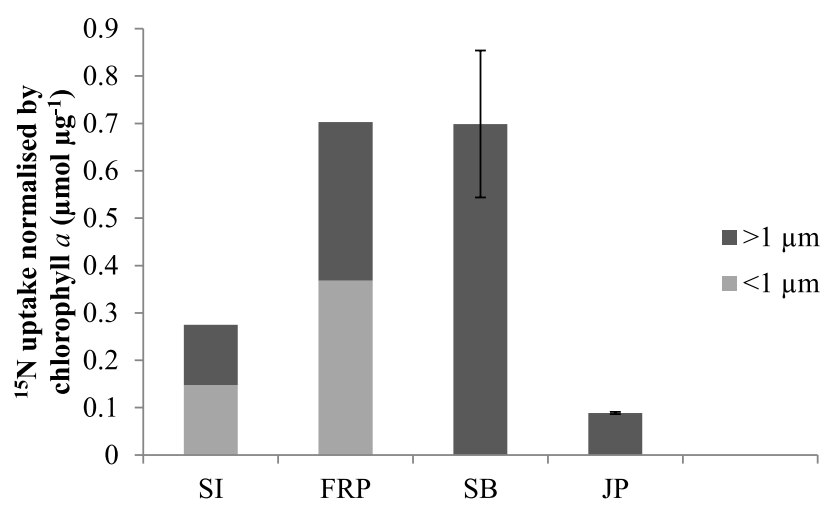

Figure 3. Uptake of ${ }^{15} \mathrm{~N}$ normalised by initial chlorophyll $a$ concentrations by the $>1 \mu \mathrm{m}$ and $<1 \mu \mathrm{m}$ fractions in treatments with lysate addition for Saanich Inlet (SI), Fraser River Plume (FRP), Semiahoo Bay (SB), and Jericho Pier (JP). Error bars are standard error of triplicate incubations for $\mathrm{SB}$, and range of duplicate incubations for JP. SI and FRP are singleton measurements.

\subsection{Remineralisation of nitrogen in bacterial lysates}

The increase in bacterial abundance in all experiments, along with the production of ammonium in the laboratory experiment, establishes that bacterial lysates produced through viral infection are available for bacterial growth and ammonium remineralisation. In the laboratory, every treatment with added lysate had a greater increase in bacteria than treatments without lysate, indicating that the bacteria used the added lysate for growth. For all field studies, bacterial abundances increased significantly in the treatments with lysate over the controls ( $p<0.05$; Fig. 2$)$, demonstrating uptake of lysis products by the bacterial communities.

Ammonium concentration increased 8-fold in laboratory treatments with lysate added to bacteria (Bac + lysate; Fig. 1b) from remineralisation of $\mathrm{N}$ in the lysate by the bacterial community. In the other treatments, either lysate was not added as a source of DON (treatment Bac) or Synechococcus was present and consumed the ammonium that was produced (the remainder of the treatments). There was no mea- sured ammonium production in the field studies except in the Fraser River Plume (FRP; Fig. 2). The increase in ammonium at the final time point in FRP may be due to the concurrent rapid increase in bacteria, which likely resulted in increased ammonium remineralisation. There was some ammonium in the added lysate (see Fig. 1b, $T=0$ ), which was present because the Vibrio PWH3a was in exponential growth to facilitate maximum lysis by PWH3a-P1, and so not all the ammonium in the medium was taken up by the bacteria prior to lysis. However, the amount that was added was minor relative to the ammonium that was produced by remineralisation. The data clearly show that lysates were used by the bacterial community for growth, and excess $\mathrm{N}$ remineralised to produce ammonium.

Although viruses (PWH3a-P1) were present in the bacterial lysate, it is unlikely that they would infect members of the bacterial community. Vibrio phages are typically speciesspecific, and often strain-specific (Comeau et al., 2005), and experiments have shown undetectable binding of PWH3a-P1 to natural populations of bacteria, even in the environment from which it was isolated (Hennes et al., 1995). Finally, even if PWH3a-P1 were able to bind to Vibrio spp., the estimated abundance of Vibrio spp. in BC coastal waters ranges from $\sim 1 \mathrm{~mL}^{-1}$ to several hundred $\mathrm{mL}^{-1}$ (Comeau and Suttle 2007), and is not enough to significantly affect $\mathrm{N}$ release. Moreover, this would not affect the observation that $\mathrm{N}$ released by viral lysis is incorporated into cells.

\subsection{Phytoplankton uptake of remineralised nitrogen}

This study shows that remineralised $\mathrm{N}$ from viral lysis of bacteria can fuel the growth of primary producers. Observations of increased ammonium production in the presence of viral lysis (Haaber and Middelboe, 2009; Shelford et al., 2012), are extended by this study, which demonstrates that bacteria remineralise the organic $\mathrm{N}$ in lysates and produce ammonium, which is then taken up by primary producers. The use of a cultivated bacterium for lysate production limits generalisation of quantitative data to environmental systems; however, the observation that $74 \%$ of the $\mathrm{N}$ in bacterial lysates 
was taken up by cultures of Synechococcus provides strong evidence that $\mathrm{N}$ from lysates is available to phytoplankton.

DON from bacterial lysates was remineralised by the bacterial assemblage into ammonium and used to fuel primary production. In the laboratory experiment, the increase in ammonium in the Bac + lysate treatment did not occur in the treatment with Synechococcus (Syn + Bac + lysate; Fig. 1b), indicating that the remineralised ammonium was taken up and led to the concurrent increase in Synechococcus cells (Fig. 1a). The increase in Synechococcus in treatment Syn + lysate may have resulted from remineralisation by contaminating bacteria (bacteria in the non-axenic Synechococcus culture, or from uninfected Vibrio PWH3a in the lysate), or possibly from direct DON uptake, although preliminary experiments indicated that direct uptake of DON was not significant.

All four field studies showed that ${ }^{15} \mathrm{~N}$ from labeled bacterial lysate was taken up by the $>1 \mu \mathrm{m}$ fraction (Fig. 3), which demonstrates that remineralised $\mathrm{N}$ in lysate supports primary production, as suggested previously (Weinbauer et al., 2011; Shelford et al., 2012). The reason that increases in phytoplankton or chlorophyll were not observed is likely that there are often significant lags between incorporation of ammonium and growth in N-limited phytoplankton (Collos, 1986; Davidson et al., 1992). As well, these rates represent minimum estimates, as ${ }^{15} \mathrm{~N}$ released through rapid recycling of lysis products (Noble and Fuhrman, 1999) or phytoplankton exudation (Bronk and Ward, 2000) is not included. Uptake of $\mathrm{DO}^{15} \mathrm{~N}$ concurrent with ${ }^{15} \mathrm{NH}_{4}$ could also have resulted in an underestimation of $\mathrm{N}$ uptake from remineralisation. The ability of phytoplankton to take up DON directly varies greatly, and is dependent on factors such as trophic status of the environment and the species of phytoplankton present (Berman and Bronk, 2003) but is generally less important than inorganic sources of $\mathrm{N}$. Although the field experiments do not provide quantitative estimates of the amount of $\mathrm{N}$ in lysate that was taken up, the results corroborate those from the laboratory experiment and indicate that $\mathrm{N}$ uptake from lysates occurs. The anomalous result in the SB experiment that the estimated uptake $\left(0.67 \pm 0.02 \mu \mathrm{mol} \mathrm{L}^{-1} \mathrm{~N}\right.$; corrected for 90 atom $\%{ }^{15} \mathrm{~N}$; Fig. 3) was more than the calculated $\mathrm{N}$ added $\left(0.44 \mu \mathrm{mol} \mathrm{L}{ }^{-1} \mathrm{~N}\right.$; Table 3$)$ suggests that the $\mathrm{N}$ in the lysate was underestimated. This is plausible, as lysate $\mathrm{N}$ was calculated from the cellular $\mathrm{N}$ quota multiplied by the decline in abundance of Vibrio PWH3a, and cell count data were not replicated. Nonetheless, the data are convincing that most of the lysate added in the SB and JP experiments was incorporated by primary producers, since at both stations $100 \%$ of the estimated ${ }^{15} \mathrm{~N}$ uptake was into the $>1 \mu \mathrm{m}$ fraction. Interestingly, we did not find a relationship between ambient concentrations of nitrate, phosphate, or ammonium and ammonium uptake despite evidence of an increase in uptake of lysis products with lower trophic status in previous studies (e.g. Noble and Fuhrman, 1999), although this could be due to all the stations in these studies being relatively productive.
Nonetheless, not all the $\mathrm{N}$ in lysates was taken up by primary producers. Although bacteria can remineralise lysate (Bac + lysate; Fig. 1b), and Synechococcus can use remineralised $\mathrm{N}$ from co-occurring bacteria (Syn + lysate; Fig. 1a), in the laboratory only $74 \%$ of the $\mathrm{N}$ in the lysate contributed to an increase in Synechococcus abundance. As well, in the FRP and SI samples, only about half of the ${ }^{15} \mathrm{~N}$ uptake was into the $>1 \mu \mathrm{m}$ fraction. Discrepancies between $\mathrm{N}$ uptake and phytoplankton growth are likely because of the lag between ammonium uptake and growth that is observed in many $\mathrm{N}$ limited phytoplankton (Collos, 1986), and because phytoplankton can take up substantially more $\mathrm{N}$ than they incorporate because of DON release (Bronk et al., 1994). As well, longer incubation times may have allowed the in situ bacterial communities to break down more complex DON in the lysate and regenerate additional ammonium that could be incorporated (Middelboe and Jørgensen, 2006), but would add the additional complication of secondary release and uptake of labeled DON. For SI and FRP, lysate N was added at relatively high concentrations (Table 3 ), which may have led to incomplete incorporation. In contrast, lysate $\mathrm{N}$ was added at much lower concentrations in the SB and JP experiments, and the ${ }^{15} \mathrm{~N}$ in the lysate was completely recovered in the particulate fraction. Finally, the incomplete transfer of $\mathrm{N}$ from lysate to Synechococcus in the laboratory, relative to the complete uptake of ${ }^{15} \mathrm{~N}$ at SB and JP, may indicate that complete remineralisation of the DON depends on the make-up of the bacterial assemblage, or that N uptake of Synechococcus was saturated.

Laboratory experiments were conducted on Synechococcus cultures grown under a low $\mathrm{N}: \mathrm{P}$ ratio and which were transitioning from exponential growth, to ensure $\mathrm{N}$ limitation but not starvation and potential cell death with release of DOM. The bacterial community (Bac) in these experiments was unlikely N-limited, and most likely C-limited, given nitrate in the medium and the production of ammonium in the $\mathrm{Bac}+$ lysate treatment. The experiment was designed to show ammonium production by the bacterial community (Bac + lysate), and its subsequent use by Synechococcus (Syn + Bac + lysate).

The increase in Synechococcus abundance in the laboratory experiment (Fig. 1a) can be explained by the different sources of $\mathrm{N}$ present in the experimental treatment $($ Syn + Bac + lysate $)$. The increase can be attributed as follows (calculated from the increase in cell number multiplied by cell quota): (1) $16.7 \mu \mathrm{mol} \mathrm{L}^{-1} \mathrm{~N}$ from the $21.3 \mu \mathrm{M}$ of nitrate in the Bac ultrafiltrate, (2) $9.2 \mu \mathrm{mol} \mathrm{L}^{-1} \mathrm{~N}$ from remineralisation of ammonium by the added bacterial assemblage, and (3) $9.8 \mu \mathrm{mol} \mathrm{L}^{-1} \mathrm{~N}$ from the uptake of ammonium from remineralisation by heterotrophic bacteria in the Synechococcus culture. Despite evidence for direct uptake of DON by phytoplankton (see Bronk et al., 2007, for a review), preliminary experiments showed no evidence for uptake of $\mathrm{N}$ from Vibrio PWH3a lysate by axenic Synechococcus. Despite the addition of $\mathrm{N}$ from other sources, the results clearly 
show that remineralisation of $\mathrm{N}$ from the lysate contributed to the increase in Synechococcus in the Syn + Bac + lysate treatment.

\subsection{Ecological implications and future directions}

Some studies have focused on the influence of phytoplankton lysates on fueling bacterial production (Gobler et al., 1997; Haaber and Middelboe, 2009), which can be especially important in certain situations, such as bloom termination (Brussaard et al., 2005). In contrast, 10 to $20 \%$ of heterotrophic bacteria are estimated to be lysed every day by viruses (Suttle, 1994), although it can vary widely (e.g. Wilhelm et al., 1998, 2002). With an estimated $3.6 \times 10^{28}$ prokaryotic cells in the upper $200 \mathrm{~m}$ of the ocean and an average carbon quota of $2.0 \times 10^{-14} \mathrm{~g} \mathrm{cell}^{-1}$ (Whitman et al., 1998), a bacterial C : $\mathrm{N}$ of approximately 5 (Goldman et al., 1987), and estimated loss rates of $10 \%$ day $^{-1}$ from viral lysis, approximately $1.44 \times 10^{13} \mathrm{~g} \mathrm{~N} \mathrm{day}^{-1}$ is released from viral lysis of bacteria in the photic zone. Primary production is estimated to be $\sim 1.35 \times 10^{14} \mathrm{~g} \mathrm{C}$ day $^{-1}$ (Ducklow and Carlson, 1992), corresponding to $\sim 2.04 \times 10^{13} \mathrm{~g} \mathrm{~N}$ day $^{-1}$ assuming the Redfield ratio $(106 \mathrm{C}: 16 \mathrm{~N})$. Therefore, an estimated $71 \%$ of global primary production could be supported by $\mathrm{N}$ released by viral lysis of bacteria. While these estimates need to be verified, evidence suggests that viral lysis supplies a substantial portion of the $\mathrm{N}$ required for primary production, and emphasises the importance of the viral shunt, especially in $\mathrm{N}$-limited regions.

The use of $\mathrm{N}$ by phytoplankton from bacterial remineralisation of DOM originating from viral lysis of bacteria indicates that viruses are not simply $\mathrm{C}$ sinks that disrupt trophic levels (Azam and Worden, 2004) but are important facilitators in $\mathrm{N}$ recycling pathways. Traditional food chain models state that $\mathrm{C}$ and other nutrients flow from primary producers to higher trophic levels. The introduction of the microbial loop (Azam et al., 1983) included bacterial dynamics, whereby DOM produced by the members of the traditional food chain is taken up by bacteria and reintroduced to the food web instead of being lost to the system. The viral shunt (Wilhelm and Suttle, 1999) introduced viruses as a "short-circuit", removing particulate $\mathrm{C}$ from primary producers, consumers, and bacteria to the pool of organic matter. This model emphasises viruses as a loss mechanism of food web $\mathrm{C}$; however, implicit in these models is that nutrients, as well as $\mathrm{C}$, must also be released by viral lysis, and that $\mathrm{N}$ and $\mathrm{P}$ are likely recycled with greater efficiency than C (Suttle, 2007). The loss of $C$ from the particulate pool is clear, but there is evidence of increased productivity in the presence of viruses. In Fe-limited regions of the eastern $\mathrm{Pa}$ cific Ocean, viruses were shown to liberate Fe into the DOM pool, where it was available for uptake by primary producers (Poorvin et al., 2004). Weinbauer et al. (2011) provided evidence for this phenomenon when they removed the viral fraction from a cyanobacteria bloom and primary production ceased. Shelford et al. (2012) confirmed that observation by demonstrating a reduction in both ammonium remineralisation and phytoplankton abundance with removal of viruses. The current study demonstrated in four separate field experiments that $\mathrm{N}$ is transferred from bacterial lysates to phytoplankton. Weinbauer et al. (2011) hypothesised that lysates either directly provided nutrients supporting Synechococcus growth or that bacteria provided inorganic nutrients by remineralising the products of viral lysis. This study demonstrates that remobilisation of nutrients by viral lysis of bacteria and subsequent remineralisation by uninfected bacteria can fuel the growth of primary producers.

Data availability. The underlying research data are provided in the Supplement.

Supplement. The supplement related to this article is available online at: https://doi.org/10.5194/bg-15-809-2018-supplement.

Author contributions. EJS and CAS designed the experiments. EJS performed the experiments and analysed the samples except for the stable isotope data, which were analysed by the Stable Isotope Facility at UC Davis, and the nitrogen cell content, which was analysed by Maureen Soon at UBC. EJS prepared the manuscript and analysed the data with contributions and guidance from CAS.

Competing interests. The authors declare that they have no conflict of interest.

Acknowledgements. We acknowledge the crew of the CGS Vector; Maureen Soon of UBC for nutrient analyses; Chris Payne for analyses and cruise technician expertise; Amy M. Chan, Julia A. Gustavsen, Marli Vlok, and Danielle M. Winget for help with experimental set-up, logistics, and discussions; Maite T. Maldonado, Philippe D. Tortell, Cheryl E. T. Chow, Caroline Chénard, Julia A. Gustavsen, and Jan F. Finke for their insights on the manuscript; and Rui Zhang and two anonymous referees for their constructive comments. This work was supported by awards from the Natural Sciences and Engineering Research Council of Canada (NSERC), UBC, and the NSERC CREATE BRITE program to Emma J. Shelford, and by NSERC Discovery and Shiptime grants, as well as infrastructure awards from the Canada Foundation for Innovation and the British Columbia Knowledge Development Fund to Curtis A. Suttle.

Edited by: Koji Suzuki

Reviewed by: Rui Zhang and two anonymous referees 


\section{References}

Azam, F., Fenchel, T., Field, J. G., Gray, J. S., Meyer-Reil, L. A., and Thingstad, F.: The ecological role of water-column microbes in the sea, Mar. Ecol. Prog. Ser., 10, 257-263, 1983.

Azam, F. and Worden, A. Z.: Microbes, molecules, and marine ecosystems, Science, 303, 1622-1624, 2004.

Berges, J. A., Franklin, D. J., and Harrison, P. J.: Evolution of an artificial seawter medium: improvements in enriched seawater, artificial water over the last two decades, J. Phycol., 37, 11381145, 2001.

Berman, T. and Bronk, D. A.: Dissolved organic nitrogen: a dynamic participant in aquatic ecosystems, Aquat. Microb. Ecol., 31, 279-305, 2003.

Bronk, D. A. and Ward, B. B.: Magnitude of dissolved organic nitrogen release relative to gross nitrogen uptake in marine systems, Limnol. Oceanogr., 45, 1879-1883, 2000.

Bronk, D. A., Glibert, P. M., and Ward, B. B.: Nitrogen uptake, dissolved organic nitrogen release, and new production., Science, 265, 1843-1846, https://doi.org/10.1126/science.265.5180.1843, 1994.

Bronk, D. A., See, J. H., Bradley, P., and Killberg, L.: DON as a source of bioavailable nitrogen for phytoplankton, Biogeosciences, 4, 283-296, https://doi.org/10.5194/bg-4-283-2007, 2007.

Brussaard, C. P. D.: Optimization of procedures for counting viruses by flow cytometry, Appl. Environ. Microb., 70, 1506-1513, https://doi.org/10.1128/AEM.70.3.1506-1513.2004, 2004.

Brussaard, C. P. D., Gast, G. J., van Duyl, F. C., and Riegman, R.: Impact of phytoplankton bloom magnitude on a pelagic microbial food web, Mar. Ecol. Prog. Ser., 144, 211-221, 1996.

Brussaard, C. P. D., Kuipers, B., and Veldhuis, M. J. W.: A mesocosm study of Phaeocystis globosa population dynamics, Harmful Algae, 4, 859-874, https://doi.org/10.1016/j.hal.2004.12.015, 2005.

Collos, Y.: Time-lag algal growth dynamics: biological constraints on primary production in aquatic environments, Mar. Ecol. Prog. Ser., 33, 193-206, 1986.

Comeau, A. M. and Suttle, C. A.: Distribution, genetic richness and phage sensitivity of Vibrio spp. from coastal British Columbia, Environ. Microbiol., 9, 1790-1800, 2007.

Comeau, A. M., Buenaventura, E., and Suttle, C. A.: A persistent, productive and seasonally dynamic vibriophage population within Pacific Oysters (Crassostrea gigas), Appl. Environ. Microb., 71, 5324-5331, 2005.

Davidson, K., Flynn, K. J., and Cunningham, A.: Non-steady state ammonium-limited growth of the marine phytoflagellate, Isochrysis galbana Parke, New. Phytol., 122, 433-438, 1992.

Ducklow, H. W. and Carlson, C. A.: Oceanic bacterial production, in: Advances in microbial ecology, edited by: Marshall, K., Plenum Press, New York, USA, 12, 113-181, 1992.

Edler, L. and Elbrächter, M.: The Utermöhl method for quantitative phytoplankton analysis, in Microscopic and molecular methods for quantitative phytoplankton analysis, edited by: Karlson, B., Cusack, C., and Bresnan, E., UNESCO, Paris, France, 13-20, 2010.

Fouilland, E., Tolosa, I., Bonnet, D., Bouvier, C., Bouvier, T., Bouvy, M., Got, P., Le Floc'h, E., Mostajir, B., Roques Richard Sempéré, C., Sime-Ngando, T., and Vidussi, F.: Bacterial carbon dependence on freshly produced phytoplankton exudates un- der different nutrient availability and grazing pressure conditions in coastal marine waters, FEMS Microbiol. Ecol., 87, 757-769, https://doi.org/10.1111/1574-6941.12262, 2014.

Fuhrman, J. A.: Marine viruses and their biogeochemical and ecological effects, Nature, 399, 541-548, 1999.

Gasol, J. M. and Del Giorgio, P. A.: Using flow cytometry for counting natural planktonic bacteria and understanding the structure of planktonic bacterial communities, Sci. Mar., 64, 197-224, 2000.

Gobler, C. J., Hutchins, D. A., Fisher, N. S., Cosper, E. M., and Sañudo-Wilhelmy, S.: Release and bioavailability of C, N, P Se, and $\mathrm{Fe}$ following viral lysis of a marine chrysophyte, Limnol. Oceanogr., 42, 1492-1504, 1997.

Goldman, J. C., Caron, D. A., and Dennett, M. R.: Regulation of gross growth efficiency and ammonium regeneration in bacteria by substrate $\mathrm{C}: \mathrm{N}$ ratio, Limnol. Oceanogr., 32, 1239-1252, 1987.

Haaber, J. and Middelboe, M.: Viral lysis of Phaeocystis pouchetii: implications for algal population dynamics and heterotrophic C, N and P cycling, ISME J., 3, 430-441, https://doi.org/10.1038/ismej.2008.125, 2009.

Healey, F. P. and Hendzel, L. L.: Indicators of phosphorus and nitrogen deficiency in five algae in culture, J. Fish. Res. Board Can., 36, 1364-1369, 1979.

Hennes, K. P., Suttle, C. A., and Chan, A. M.: Fluorescently labeled virus probes show that natural virus populations can control the structure of marine microbial communities, Appl. Environ. Microb., 61, 3623-3627, 1995.

Hollibaugh, J. T.: Nitrogen regeneration during the degradation of several amino acids by plankton communities collected near Halifax, Nova Scotia, Mar. Biol., 45, 191-201, 1978.

Holmes, R. M., Aminot, A., Kerouel, R., Hooker, B. A., and Peterso, B. J.: A simple and precise method for measuring ammonium and marine and freshwater ecosystems, Can. J. Fish Aquat. Sci., 56, 1801-1808, 1999.

Middelboe, M. and Jørgensen, N. O. G.: Viral lysis of bacteria: an important source of dissolved amino acids and cell wall compounds, J. Mar. Biol. Assoc. UK, 86, 605-612, 2006.

Middelboe, M., Jørgensen, N. O. G., and Kroer, N.: Effects of viruses on nutrient turnover and growth efficiency of noninfected marine bacterioplankton, Appl. Environ. Microb., 62, 19911997, 1996.

Middelboe, M., Riemann, L., Steward, G., Hansen, V., and Nybroe, O.: Virus-induced transfer of organic carbon between marine bacteria in a model community, Aquat. Microb. Ecol., 33, $1-10,2003$.

Noble, R. T. and Fuhrman, J. A.: Breakdown and microbial uptake of marine viruses and other lysis products, Aquat. Microb. Ecol., 20, 1-11, 1999.

Olson, R. J., Zettler, E. R., and DuRand, D. M.: Phytoplankton analysis using flow cytometry, in handbook of methods in aquatic microbial ecology, Lewis Publishers, Boca Raton, FL, USA, 175186, 1993.

Parsons, T. R., Maita, Y., and Lalli, C. M.: Manual of chemical and biological methods for seawater analysis, Pergamon Press, New York, USA, 107-108, 1984.

Poorvin, L., Rinta-Kanto, J. M., Hutchins, D. A., and Wilhelm, S. W.: Viral release of iron and its bioavailability to marine plankton, Limnol. Oceanogr., 49, 1734-1741, 2004. 
Poorvin L., Sander S. G., Velasquez I., Ibisanmi E., LeCleir G. R., and Wilhelm S. W.: A comparison of Fe bioavailability and binding of a catecholate siderophore with virus-mediated lysates from the marine bacterium Vibrio alginolyticus PWH3a, J. Exp. Mar. Biol. Ecol., 399, 43-47, 2011.

Shelford, E. J., Middelboe, M., Møller, E. F., and Suttle, C. A.: Virus-driven nitrogen cycling enhances phytoplankton growth, Aquat. Microb. Ecol., 66, 41-46, https://doi.org/10.3354/ame01553, 2012.

Suttle, C. A.: The significance of viruses to mortality in aquatic microbial communities, Microb. Ecol., 28, 237-243, https://doi.org/10.1007/BF00166813, 1994.

Suttle, C. A.: Viruses in the sea, Nature, 437, 356-361, https://doi.org/10.1038/nature04160, 2005.

Suttle, C. A.: Marine viruses-major players in the global ecosystem., Nat. Rev. Microbiol., 5, 801-812, https://doi.org/10.1038/nrmicro1750, 2007.

Suttle, C. A., Chan, A. M., and Cottrell, M. T.: Use of ultrafiltration to isolate viruses from seawater which are pathogens of marine phytoplankton, Appl. Environ. Microb., 57, 721-726, 1991.

Suttle, C. A. and Chen, F.: Mechanisms and rates of decay of marine viruses in seawater, Appl. Environ. Microb., 58, 3721-3729, 1992.

Weinbauer, M. G., Wilhelm, S. W., Suttle, C. A., and Garza, D. R.: Photoreactivation compensates for UV damage and restores infectivity to natural marine virus communities, Appl. Environ. Microb., 63, 2200-2205, 1997.
Weinbauer, M. G., Bonilla-Findji, O., Chan, A. M., Dolan, J. R., Short, S. M., Šimek, K., Wilhelm, S. W., and Suttle, C. A. Synechococcus growth in the ocean may depend on the lysis of heterotrophic bacteria, J. Plankton Res., 33, 1465-1476, https://doi.org/10.1093/plankt/fbr041, 2011.

Whitman, W. B., Coleman, D. C., and Wiebe, W. J.: Prokaryotes: the unseen majority, P. Natl. Acad. Sci. USA, 95, 6578-6583, 1998.

Wilhelm, S. W. and Suttle, C. A.: Viruses and nutrient cycles in the sea, Bioscience, 49, 781-788, https://doi.org/10.2307/1313569, 1999.

Wilhelm, S. W., Weinbauer, M. G., Suttle, C. A., and Jeffrey, W. H.: The role of sunlight in the removal and repair of viruses in the sea, Limnol. Oceanogr., 43, 586-592, 1998.

Wilhelm, S. W., Brigden, S. M., and Suttle, C. A.: A dilution technique for the direct measurement of viral production: a comparison in stratified and tidally mixed coastal waters, Microb. Ecol., 43, 168-173, https://doi.org/10.1007/s00248-001-1021-9, 2002.

Yin, K., Liu, H., and Harrison, P. J.: Sequential nutrient uptake as a potential mechanism for phytoplankton to maintain high primary productivity and balanced nutrient stoichiometry, Biogeosciences, 14, 2469-2480, https://doi.org/10.5194/bg-142469-2017, 2017. 